\title{
PENGEMBANGAN WEBSITE KELURAHAN KOTA BAMBU UTARA JAKARTA
}

\author{
Dedi Trisnawarman', Tri Sutrisno ${ }^{2}$, dan Viny Christanti ${ }^{3}$ \\ ${ }^{I}$ Program Studi Sistem Informasi, Universitas Tarumanagara \\ Email: dedit@fti.untar.ac.id \\ ${ }^{2,3}$ Program Studi Teknik Informatika, Universitas Tarumanagara
}

\begin{abstract}
The government is mandated to convey information to public related to the administration of government affairs, both planning, implementation and achievement of development results. The right media to support the achievement of this mandate is a Kelurahan website. Currently, the development of Kota Bambu Utara Urban Village has not been optimally disseminated to the community, so it is necessary to carry out Community Service (PkM) activities with the creation and implementation of the Kota Bambu Utara Urban Village website. The purpose of this PkM activity is to build a Kelurahan website. The method used in this PkM activity is a software development method, namely the prototyping method. The stages of the prototyping method begin with the planning stage, fulfillment of system requirements, and interactive user involvement in each stage until the last stage, namely the implementation stage. The software used is PHP and MySQL. While the CMS software is wordpress with a paid template for making web designs. The results achieved in the implementation of PkM activities are a website with menus such as: Home, Profile, Information, Services and Institutions. They can be used to convey information about village administration activities and also be used for promotional activities. In addition, the community can also provide input to the North Bambu City Urban Village Government related to government administration such as public services, development activities and so on. The website that was built can also be used for archiving documents for the activities of the North Bamboo City Urban Village Government.
\end{abstract}

Keywords: website, kelurahan, information, community

\begin{abstract}
ABSTRAK
Pemerintahan diamanatkan untuk menyampaikan informasi kepada masyarakat terkait dengan penyelenggaraan urusan pemerintahan, baik perencanaan,, pelaksanaan maupun capaian hasil pembangunan. Media yang tepat untuk mendukung tercapainya amanat tersebut adalah sebuah website Kelurahan. Saat ini perkembangan Kelurahan Kota Bambu Utara belum disosialisasikan secara optimal kepada masyarakat, sehingga perlunya dilakukan kegiatan Pengabdian kepada Masyarakat (PkM) dengan Pembuatan dan implementasi website Kelurahan Kota Bambu Utara. Untuk itu maka tujuan kegiatan PkM ini adalah membangun website Kelurahan. Metode yang digunakan dalam kegiatan PkM ini adalah metode pengembangan perangkat lunak yaitu metode prototyping. Tahapan metode prototyping dimulai dengan tahapan perencanaan, pemenuhan syarat-syarat kebutuhan sistem, dan terlibatnya user secara interaktif dalam setiap tahapan sampai tahap terakhir yaitu tahap implementasi. Perangkat lunak yang digunakan adalah PHP dan MySQL. Sedangkan perangkat lunak CMS yaitu wordpress dengan template yang berbayar untuk pembuatan desain web. Hasil yang dicapai dalam kegiatan Pelaksanaan kegiatan PkM ini adalah sebuah website dengan menu seperti: Beranda, Profil, Informasi, Pelayanan dan Lembaga. Menu-menu tersebut dapat digunakan untuk menyampaikan informasi seputar kegiatan penyelenggaraan pemerintahan kelurahan dan dapat juga digunakan untuk kegiatan promosi. Selain itu masyarakat juga dapat memberikan masukan kepada Pemerintahan Kelurahan Kota Bambu Utara yang terkait dengan penyelenggaraan pemerintahan seperti pelayanan publik, kegiatan pembangunan dan sebagainya. Website yang dibangun juga dapat digunakan untuk pengarsipan dokumen-dokumen kegiatan Pemerintahan Kelurahan Kota bambu utara.
\end{abstract}

Kata kunci: website, kelurahan, informasi, masyarakat

\section{PENDAHULUAN}

Sesuai dengan Inpres nomor 3 tahun 2003, tentang kebijakan dan strategi nasional pengembangan $e$-Government, seluruh instansi-instansi pemerintah diminta untuk membangun jaringan internet dan mengimplementasikan e-Government bagi pelayanan masyarakat. Hal tersebut dikarenakan efektifitas dari jaringan internet untuk penyebaran informasi yang dibutuhkan masyarakat.

Populasi pemakai internet di dunia diperkirakan akan makin cepat menyebar seiring dengan dukungan teknologi dan infrastruktur yang makin murah dan terjangkau. Pengguna internet di dunia tumbuh dengan pesat, begitu juga di Indonesia. Berdasarkan data statistik per tanggal 30 
Desember 2018, terdapat 2,199,428,570 orang pengguna internet di dunia, dan pada tanggal 30 Juni 2019 terdapat 143,260,000 orang pengguna internet di Indonesia atau berjumlah lebih dari $53,2 \%$ dari jumlah populasi penduduk Indonesia (Internet World Stats, 2019),

McLuhan (2001) menggambarkan internet sebagai kampung global, yang memudahkan masyarakat dalam berkomunikasi dan melibatkan komunitas masyarakat banyak. Masyarakat dapat berinteraksi dan dapat menggunakan internet sebagai solusi bagi masalah sebagian besar masyarakat tanpa terhalang jarak dan tempat.

Beberapa penelitian tentang pengembangan website desa/kelurahan sudah pernah dipublikasikan, diantaranya oleh Supryanta dan Nisa (2015) mengembangkan Website desa wisata Karangrejo Loano. Website yang dikembangkan memuat informasi seputar kekayaan alam yang dapat dijadikan tujuan wisata. Mansur dan Kasmawi (2017), membangun website yang dapat digunakan sebagai portal bagi sistem basis data desa terpadu. Dalam website yang dikembangkan dimungkinkan untuk setiap desa mengembangkan halaman website masing-masing, yang memuat informasi mengenai profil, kegiatan, berita dan informasi yang ingin disampaikan ke masyarakat. Selanjutnya Sutrisno dan Trisnawarman (2018) dalam kegiatan PkM, menghasilkan sebuah perangkat lunak berupa website yang dapat diakses pada alamat web: www.pandowoharjo.web.id, Dalam kegiatan PkM tersebut terdapat transfer pengetahuan kepada masyarakat desa melalui pelatihan pengelolaan website. Lebih lanjut Astuti (2017) mengembangkan website desa untuk aplikasi layanan kependudukan. Aplikasi yang dibangun memiliki fungsi untuk pembuatan suratsurat yang berkaitan dengan kependudukan secara terpadu.

Pemerintahan Kelurahan Kota Bambu Utara berbatasan dengan Kelurahan Tomang di sebelah utara, dan Kelurahan Slipi di sebelah barat, terletak di kecamatan Palmerah, Jakarta Barat, Daerah Khusus Ibukota Jakarta, Indonesia. (Peraturan Menteri Dalam Negeri Nomor 137 Tahun 2017). Penduduk Kelurahan ini terdiri dari 14.924 laki-laki dan 14.333 perempuan dari keseluruhan jumlah penduduk sebanyak 29.257 pada tahun 2016 .

Peta alamat Kantor Kelurahan Kota Bambu Utara dapat diakses menggunakan google map (Gambar 1).

\section{Gambar 1}

\section{Peta Alamat Kantor Kelurahan Kota Bambu Utara}

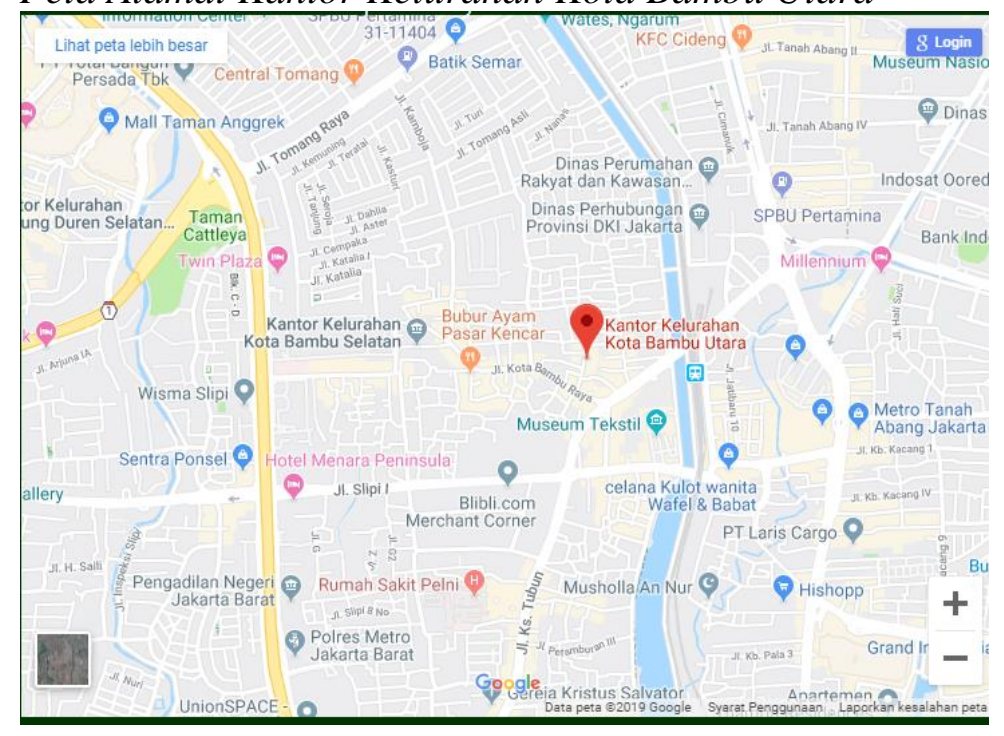




\subsection{Permasalahan Mitra}

Permasalahan yang dihadapi oleh pihak mitra yaitu Kelurahan Kota Bambu Utara adalah belum tersedianya sarana yang dapat menyediakan informasi baik dari pihak Pemerintah Kelurahan maupun masukan informasi dari masyarakat.

Jumlah penduduk yang besar dan lokasi yang terletak di Ibu Kota Negara, membuat tuntutan yang sangat tinggi terhadap layanan publik, terutama informasi yang cepat dan efektif. Pemerintahan Kelurahan Kota Bambu Utara perlu mengembangkan suatu perangkat sebagai sarana untuk memenuhi tuntutan kebutuhan warganya terhadap kebutuhan informasi.

Potensi untuk berkembang secara mandiri memiliki peluang yang makin besar sejak UU No.6 tahun 2014 tentang Desa diterapkan. Pembangunan dapat disesuaikan berdasarkan kebutuhan masing-masing desa dengan tujuan menciptakan kesejahteraan masyarakat.

Kegiatan PKM ini bertujuan untuk mengembangkan dan mengimplementasikan website Kelurahan Kota Bambu Utara. Website yang dikembangkan diharapkan dapat menampilkan informasi publik yang dibutuhkan oleh masyarakat, menjadi sarana bagi usulan dan pengaduan permasalahan masyarakat, pengumuman yang segera dapat disampaikan ke masyarakat. Website ini juga diharapkan dapat menjadi media promosi untuk lebih memperkenalkan profil Kelurahan Kota Bambu Utara.

\subsection{Solusi Mitra}

Tim pengusul menawarkan solusi bagi mitra berdasarkan kompetensi keilmuan dan pengalaman. Masalah yang terkait dengan penyampaian informasi kegiatan pembangunan kepada masyarakat dapat diatasi dengan membangun sebuah website kelurahan. Hal ini mengingat ketersediaan infrastruktur yang memadai dan sumberdaya manusia yang terdidik. Website yang dibangun selanjutnya dapat dikembangkan untuk menambahkan fitur-fitur aplikasi sistem informasi yang lain, sesuai dengan kebutuhan, seperti sistem informasi kependudukan, surat menyurat, penggajian dan sebagainya.

Manfaat dari solusi yang ditawarkan yaitu: web dapat digunakan untuk mempromosikan profil dan potensi daerah, penyebaran informasi kegiatan pemerintahan dan pembangunan, media komunikasi dan pengarsipan dokumen pemerintahan kelurahan.

\subsection{Target Luaran}

Target luaran dari kegiatan Pkm ini adalah sebuah website. Dalam website tersebut terdapat fiturfitur seperti: Beranda, Profil, Informasi, Pelayanan dan Lembaga

- Beranda (Home)

- Profil Kelurahan

- Visi Misi

- Struktur Organisasi

- Profil Kelurahan

- Peta Wilayah

- Informasi

- Pelayanan

- Lembaga

Sedangkan luaran lain dalam kegiatan PkM ini adalah sebuah publikasi ilmiah buku panduan untuk pengguna atau user manual, dan hak kekayaan intelektual. 


\section{METODE PELAKSANAAN PKM}

Metode pelaksanaan kegiatan PkM yaitu metode pengembangan perangkat lunak cepat atau yang dikenal dengan metode Rapid Application Development (RAD). Metode RAD yang digunakan berdasarkan acuan dari Dennis et al.(2015), yaitu dimulai dengan tahapan perencanaan, pemenuhan syarat-syarat kebutuhan sistem, dan terlibatnya user secara interaktif dalam setiap tahapan sampai tahap terakhir yaitu tahap implementasi, interaksi tersebut dapat dilihat seperti pada Gambar 2. Perangkat lunak yang digunakan adalah PHP dan MySQL. Sedangkan perangkat lunak CMS yaitu wordpress dengan template yang berbayar untuk pembuatan desain web.

Pengumpulan kebutuhan menggunakan metode wawancara, observasi, document examination dan riset (Connoly \& Begg, 2010).

\section{Gambar 2}

\section{Tim Pelaksana Pkm dengan Pengguna Sistem}

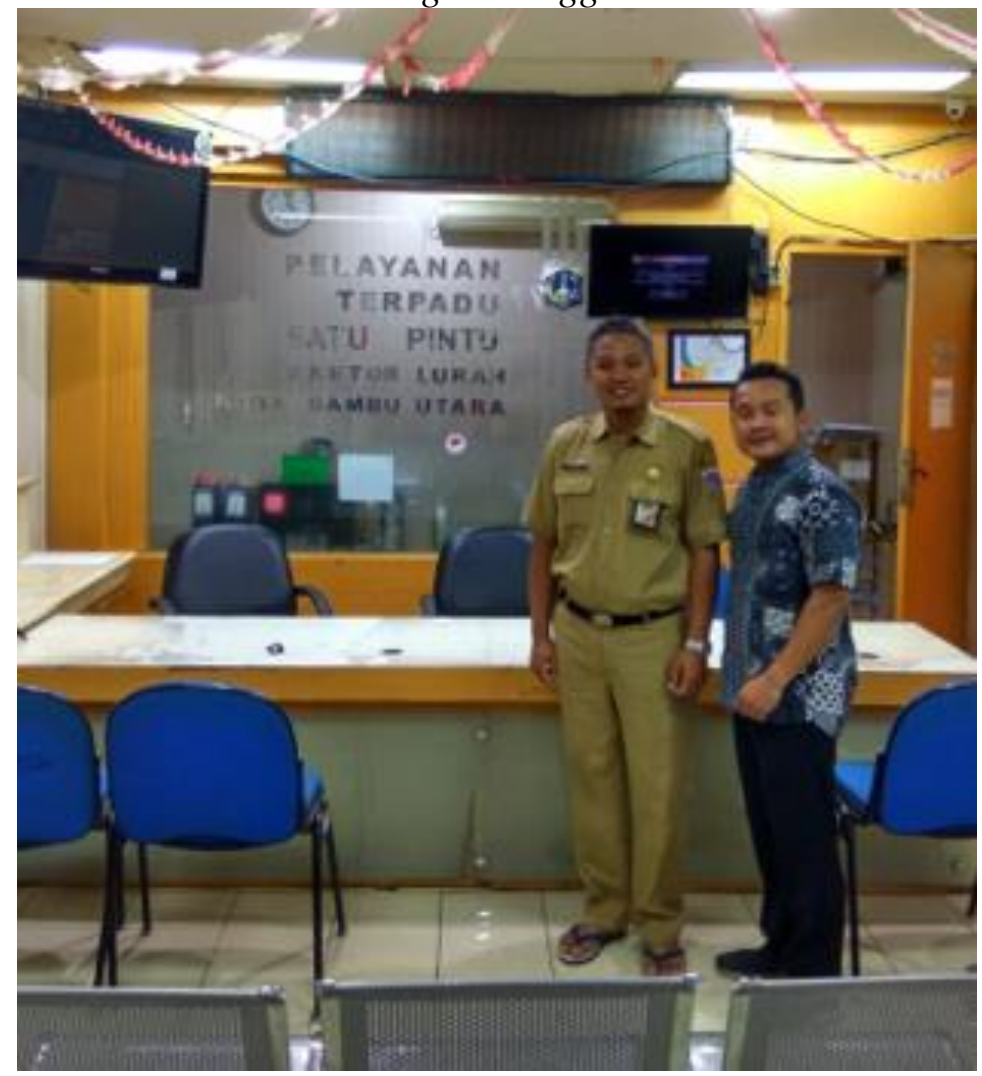

\section{HASIL DAN PEMBAHASAN}

Kegiatan PkM yang telah dilaksanakan menghasilkan luaran berupa website yang dapat diakses melalui alamat web: www.kotabambuutara.com. Kegiatan pelaksanaan PkM dilakukan pada pada bulan Agustus sampai dengan bulan Desember. Dimulai dari perencanaan penyusunan proposal dan identifikasi kebutuhan mitra. Selanjutnya proses pengembangan mengikuti tahapan metode prototyping. Tim pelaksana PkM terdiri dari tiga orang dan melibatkan 1 orang mahasiswa dari program studi sistem Informasi, sedangkan dari mitra melibatkan staf pegawai kantor Kelurahan.

\subsection{Hasil Rancangan Website}

Website Kota Bambu Utara yang telah dirancang memiliki lima menu, yaitu Beranda, Profil, Informasi, Pelayanan dan Lembaga seperti yang ditunjukan Gambar 3. 


\section{Gambar 3}

Homepage (Halaman Depan) Website Kota Bambu Utara
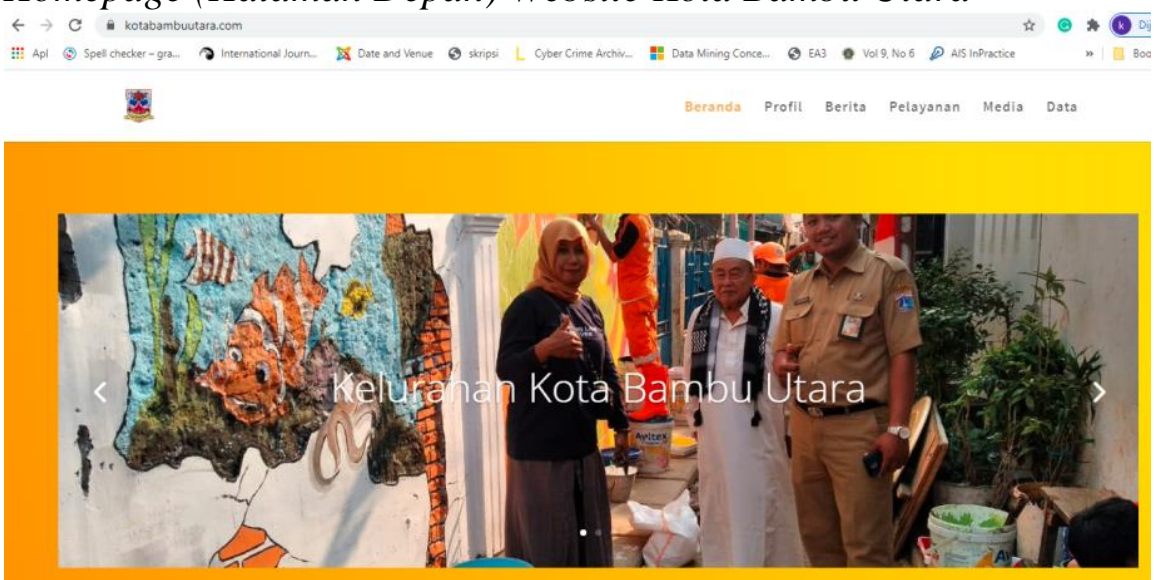

Selanjutnya jika di scroll ke bawah maka di halaman depan website, terdapat tampilan menu untuk menambahkan artikel atau informasi yang dibutuhkan, seperti yang terlihat pada Gambar 4 . Tampilan menu informasi Peta pada website Kota Bambu Utara (Gambar 5). Untuk melihat kontak dengan tambahan gambar-gambar yang informatif (Gambar 5).

\section{Gambar 4}

\section{Tampilan Selamat Datang}

se.

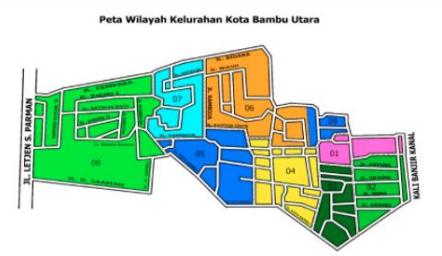

Selamat Datang di Website Kelurahan Kota

Kelurahan Kota Bambu Utara merupakan kelurahan yang terbentuk

akibat pemekaran pada tahun 1993, dari Kelurahan Kota Bambu dipecal
meniadi dua Kelurahan yaitu Kelurahan Kota Bambu Utara dat

Kelurahan Kota Bambu Selatan.

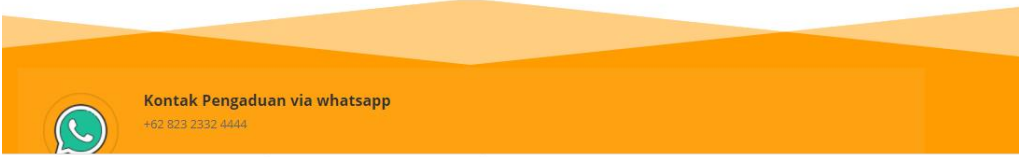

\section{Gambar 5}

\section{Halaman Profil}
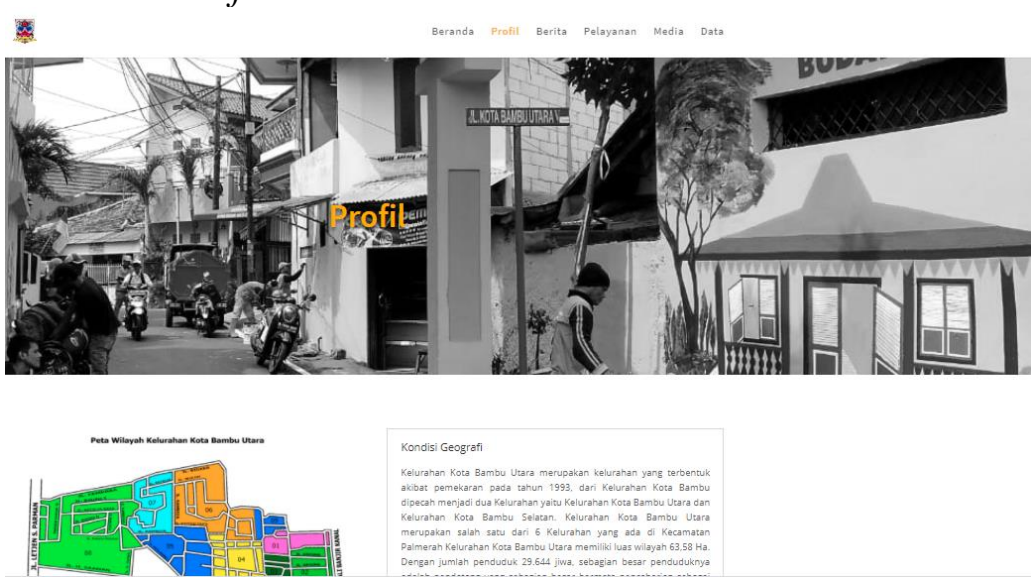


\section{Gambar 6}

Menu Kontak

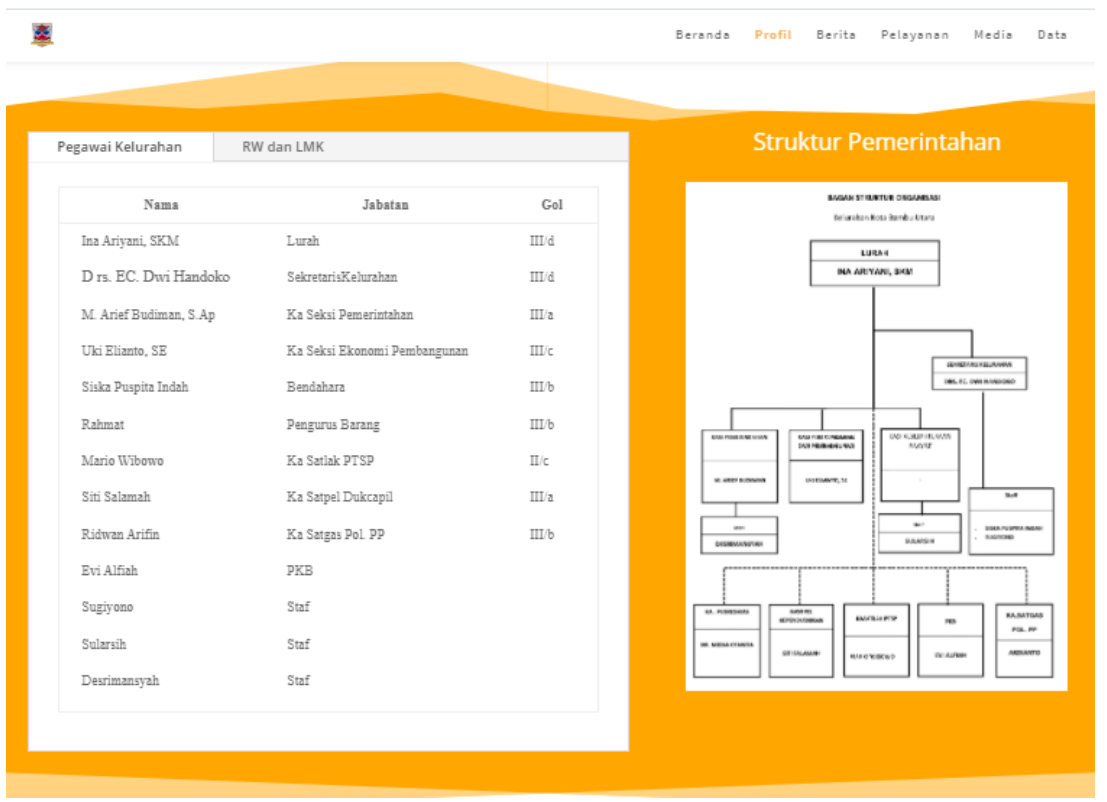

\section{KESIMPULAN DAN SARAN}

Kegiatan PkM pada Pemerintahan Kelurahan Kota Bambu Utara telah dilaksanakan, dari kegiatan tersebut dapat disimpulkan bahwa website merupakan solusi bagi kebutuhan sarana untuk menyampaikan informasi bagi masyarakat dan dapat digunakan juga sebagai media komunikasi dan promosi bagi kegiatan pemerintahan dan pembangunan Kelurahan Kota Bambu Utara. Selain sebagai media informasi dan komunikasi, perangkat lunak web yang dibangun juga dapat digunakan sebagai media pengarsipan kegiatan Pemerintahan.

Saran:

Diperlukan petugas tersendiri yang khusus bertugas mengelola website yang telah dikembangkan, dan transfer pengetahuan dalam pengelolaan web, sehingga informasi yang disampaikan selalu dapat diperbaharui.

\section{Ucapan Terima Kasih (Acknowledgement)}

Terima kasih kepada Lembaga Penelitian dan Pengabdian kepada Masyarakat Universitas Tarumanagara Jakarta (LPPM Untar) yang telah menyediakan sarana dalam pelaksanaan kegiatan PKM ini.

\section{REFERENSI}

Astuti, I. F. (2017). Sistem layanan kependudukan terpadu desa. Jurnal Informatika Mulawarman, 12(1). http://dx.doi.org/10.30872/jim.v12i1.217

Connolly, T., \& Begg, C. (2010). Database systems a practical approach to design, implementation, and management (5th ed.). Pearson Education.

Roth, R. M., Dennis, A., \& Wixom, B. H., \& (2015). Systems analysis \& design (6th ed.).Willey. Instruksi Presiden Republik Indonesia Nomor 3 Tahun 2003 tentang Kebijakan dan Strategi Nasional Pengembangan E-Government. (2003). Indonesia. https://ppidkemkominfo.files.wordpress.com/2012/12/instruksi_presiden_no_3_th_20031 .pdf

Internet World Stats. (2019). Internet 2019 usage in Asia. http://www.internetworldstats.com/stats.htm, di akses 26 Agustus 2019 
Mansur, \& Kasmawi. (2017). Pengembangan sistem database terpadu berbasis web untuk penyediaan layanan informasi website desa. Jurnal Nasional Teknologi dan Sistem Informasi, 3(1), 73-82. https://doi.org/10.25077/TEKNOSI.v3i1.2017.73-82

McLuhan, M. (2001). War and peace in the global village. Corte Madera.

Peraturan Menteri Dalam Negeri Nomor 137 Tahun 2017 tentang Kode dan Data Wilayah Administrasi Pemerintahan. Kementerian Dalam Negeri Republik Indonesia. (2017). Indonesia. https://peraturan.bpk.go.id/Home/Details/111512/permendagri-no-137-tahun2017

Sutrisno T., \& Trisnawarman D. (2018). Pembuatan dan implementasi website Desa Pandowoharjo. Jurnal Bakti Masyarakat Indonesia, 1(2), 211-220. http://dx.doi.org/10.24912/jbmi.v1i2.2905

Undang-Undang Republik Indonesia Nomor 6 Tahun 2014 tentang Desa. (2014). Indonesia. https://www.dpr.go.id/dokjdih/document/uu/UU_2014_6.pdf 